\title{
Closing
}

\section{Children as social justice activists}

\section{Tracey Malawana}

In a historic ruling that decriminalised peaceful protest, the Constitutional Court declared in its November 2018 judgment: "In particular, it must be emphasised that for children, who cannot vote, assembling, demonstrating and picketing are integral to their involvement in the political process. By virtue of their unique station in life the importance of the section 17 right [the right to protest] has special significance for children who have no other realistic means of expressing their frustrations".

The submissions made by Equal Education, as amicus curiae in the case brought by the Social Justice Coalition, argued that the ability to engage in protest action is vital for the democratic project and to the work of Equal Education members in furthering the right to basic education. As we explained to the Constitutional Court, by engaging in protest action as a mechanism of drawing attention to the problems that afflict public education, Equal Education learner members continue on a long history in the South African context of marginalised children and students using protest action as a means of struggle and political selfactualisation.

South Africa has a deep-rooted history of racial oppression and segregation. Among other things, education was used to perpetuate inequalities in the country. In 1953 the Bantu Education Act was enacted, enforcing racially separate educational facilities. The Nationalist government made it clear that this education system was designed to teach African learners to be "hewers of wood and drawers of water" for a white-owned economy and society, regardless of an individual's abilities and aspirations. As then Minister of Native Affairs, Dr Hendrik F. Verwoerd told Parliament: "There is no place for [the Bantu] in the European community above the level of certain forms of labour ... What is the use of teaching the Bantu child mathematics when it cannot use it in practice?"1

As a result of these dreadful laws, learners across the country organised to resist and reject Bantu Education. The 1976 Soweto Uprising, which occurred in response to the introduction of Afrikaans as the medium of instruction in schools, started as a series of demonstrations and protests led by black school children on the morning of 16 June 1976.

1 https://en.wikipedia.org/wiki/Bantu_Education_Act,_1953. 
The Soweto Uprising is among the most significant demonstrations of the power of children as social justice activists. The vital role that young people played in the pursuit of liberation gave us a different perspective on resistance - with boycotts as popular strategy, which required intense organising and mobilising.

In democratic South Africa, we have seen many student resistance movements, including \#FeesMustFall, \#OpenStellenbosch and \#RhodesMustFall. \#RhodesMustFall was a protest movement that began in March 2015: it called for the removal of the statue of Cecil John Rhodes from the University of Cape Town and led to a wider movement to decolonise education across South Africa. Organising and mobilising was the strategy employed by the student-based political movements, and we witnessed the influence of the Soweto Uprising in setting the paradigm for student protest.

Equal Equation members - who are predominantly high school learners - draw inspiration from all of these students' movements. Equal Education is a youth-led social movement of learners, parents, teachers and community members working for quality and equality in the South African education system, through analysis and activism, as part of a broader democratic struggle for a free, just and equal society. We organise in five provinces - Gauteng, Western Cape, Eastern Cape, KwaZulu-Natal and Limpopo - in rural and urban (township) settings. Youth group meetings, which are held weekly in all provinces, are a platform for Equal Education members to learn and deliberate about inequalities in the education system today, to conduct political education classes, to establish campaigns, to sharpen our understanding of the constitution, and ultimately to develop young activist leaders.

Most Equal Education members are not old enough to cast a vote to elect their government of choice, but they are frustrated by poor service delivery. Rather than drop out of school, learners who must endure school environments that threaten their dignity and safety, instead organise themselves, engage government leaders, take to the streets to protest, and as a last resort turn to the courts.

Multiple times, Equal Education members have been denied their right to protest - despite meeting the requirements of the Gatherings Act. The incidences include:

\section{April 2014}

Equal Education members were unlawfully denied the right to protest at the Maluti education district offices. Our demand was for teachers to be appointed to vacant posts at Moshesh High School. Despite informing the police and municipality representatives that there was no legal basis for our protest to be suppressed, they would not see reason. There was 
reason to believe that the protest would turn violent - as our track record shows, Equal Education does not have a history of violent protest. $^{2}$

\section{May 2014}

Hundreds of learners, including Equal Education members, from Sizimisele Technical School in Khayelitsha were violently dispersed by the SAPS and the Metro Police while en route to the provincial legislature, to demand that action be taken by the Western Cape Education Department to ensure an end to learners being without teachers for extended periods of time. ${ }^{3}$

\section{July 2017}

The police and the KwaZulu-Natal Department of Education shut down a peaceful protest held by members of Equal Education, as we attempted to screen our Long Walk to School film ${ }^{4}$ outside the Pietermaritzburg office of the KZN DoE. The film highlights the years of struggle of Equal Education members to secure safe and reliable scholar transport. We had in fact complied with all the formalities in the Gatherings Act, and our action was peaceful. The right to protest has been crucial as a tool to raise awareness about the inequalities we are faced with in the education system. The right to education and the right to protest are not at odds. Government must protect and fulfil both rights, primarily by fulfilling its Constitutional mandate to reverse the systemic inequality in our society, and by ensuring an end to the unlawful stifling of peaceful organising. ${ }^{5}$

Equal Education uses a range of tools in the struggle for quality education for all - from social mobilisation and community organising, to submissions to the legislative and the executive branches of government, to litigation.

Social mobilisation is the process that engage like-minded group of people like our members who are a combination of learners, teachers and parents and allows them to think and understand their situation and to organize and initiate action for their recovery with their own initiative and creativity. While organising is the establishment of effective relationship amongst our members who then come up with creative ways of petitioning, using social media and staging effective advocacy actions through campaigns and if all these fail without any official accounting, litigation is introduced to keep the momentum and clearly state the obligations that government officials committed to.

\footnotetext{
2 https://equaleducation.org.za/2014/04/30/equal-education-unlawfullydenied-the-right-to-protest-at-the-maluti-district-office/.

3 https://equaleducation.org.za/2014/05/06/police-violently-dispersepeaceful-high-school-protest-in-cape-town-but-students-secure-a-guaranteeof-teachers/.

4 https: $/ /$ www.youtube $\cdot$ com $/$ watch? $\mathrm{v}=2 \mathrm{CcM}$ FhG0O0\&t $=603 \mathrm{~s}$.

5 https://equaleducation.org.za/2017/07/12/media-statement-kzn-mecsecurity-officials-embarrassed-call-police-to-disperse-lawful-gathering/.
} 
Through these strategies we have won the adoption of Minimum Norms and Standards for School Infrastructure, the provision of scholar transport to learners in Nquthu in northern KwaZulu-Natal, dramatic improvements to school sanitation, the expansion of school feeder zones in Gauteng, and school safety being prioritised by government. South Africa has witnessed Equal Education members - particularly high school members known as Equalisers - ensure that government officials account for their failures, and raise their voices to change and shape the education system.

Conscientised learners have the power to shape what they want South Africa to be, and what they want the education system to achieve. Our approach has always been to win gains politically - but when for years provincial and national government is unresponsive we end up in the courts. We are however thankful to the judiciary for continuing to play a significant role in the realisation of what is promised to us by the Constitution.

The youth of 1976, of \#FeesMustFall, of \#RhodesMustFall, of countless other struggles, and of Equal Education is evidence that children continuously play a vital role as social justice activists both in education and in social justice as a whole. 